\title{
Standardization of clinical enzyme assays: a reference method for aspartate and alanine transaminases
}

\author{
J. H. WILKINSON, D. N. BARON, D. W. MOSS, AND P. G. WALKER
}

From Charing Cross Hospital Medical School, Royal Free Hospital School of Medicine, the Royal Postgraduate Medical School, and the Institute of Orthopaedics, London

This is the second report produced by the Working Party set up under the auspices of the Standards Subgroup of the Laboratory Development Advisory Group of the Department of Health and Social Security. The Working Party includes representatives of the Association of Clinical Biochemists, the Association of Clinical Pathologists, and the Royal College of Pathologists. Its first report, devoted to the standardization of the assay of alkaline phosphatase, has recently been published (Moss, Baron, Walker, and Wilkinson, 1971).

Aspartate and alanine transaminases have long been known in clinical biochemistry as glutamateoxaloacetate transaminase and glutamate-pyruvate transaminase respectively, but are officially recognized by the International Union of Biochemistry as L-aspartate: 2-oxoglutarate aminotransferase (EC 2.6.1.1.) and L-alanine: 2-oxoglutarate aminotransferase (EC 2.6.1.2.). Aspartate transaminase and alanine transaminase are approved trivial names and in this report these are abbreviated to AST and ALT respectively.

Several colorimetric, fluorimetric, and spectrophotometric techniques have been devised for their determination but for the purposes of standardization a spectrophotometric procedure is recommended as a reference method.

The measurement of aspartate and alanine transaminase activities, described in this report, are examples of reaction-rate techniques in which the progress of the enzyme reaction is followed throughout the period of observation. Absorbence readings are taken at intervals timed with a stopwatch or, preferably, with the aid of a recording spectrophotometer. By such means it can be verified that the reaction rate is constant. Such verification is clearly impossible with a two-point assay system. Nevertheless, within certain limits methods of the latter type can be used satisfactorily, provided they are calibrated with the aid of a suitable reference method, Received for publication 20 September 1972. such as those proposed in this report. The principles of calibration were discussed in the first report of the Working Party.

\section{Principle}

The reactions involved in the determination of aspartate transaminase (AST) activity are as follows: Aspartate + 2-oxoglutarate $\rightleftharpoons$ glutamate +

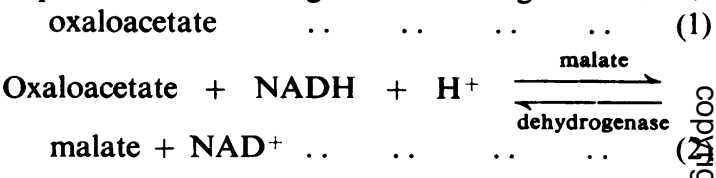
The oxaloacetate produced by the transaminase serves as substrate for malate dehydrogenase by which it is reduced to malate in the presence of dihydronicotinamide-adenine dinucleotide (NADH), which is simultaneously oxidized. NADH has an absorbence peak at $340 \mathrm{~nm}$ which is not shown by the oxidized form, and the decrease in absorbence at this wavelength provides a means for the measurement of the transaminase activity. The methods suggested are based upon those of Henry, Chiamori, Golub, and Berkman (1960) who re-investigated and improved the technique originally introduced by Karmen (1955).

The spectrophotometric procedure has an important advantage over colorimetric procedures in $ᄋ$ which the oxaloacetate produced in reaction $1 D$ is allowed to react with a chromogenic reagent such as 2,4-dinitrophenyl-hydrazine (Reitman $\bar{N}$ and Frankel, 1957) or a diazonium reagent 5 (Babson, Shapiro, Williams, and Phillips, 1962). $N$ Oxaloacetate is a potent inhibitor of AST (Boyd, $\underset{\omega}{\mathcal{E}}$ $1961)$ and in the spectrophotometric procedure is $\sigma$ removed as fast as it is formed, whereas in the colorimetric techniques it is allowed to accumulate.

The spectrophotometric procedure is standardized $\stackrel{\odot}{\rightleftharpoons}$ by reference to the molar absorbance of NADH $\left(6.22 \times 10^{3}\right)$ at $340 \mathrm{~nm}$. The decrease in unit time 
( $1 \mathrm{~min}$ ) during the rectilinear (zero order) phase of the reaction provides a means for the calculation of the enzyme activity in intcrnational units (micromoles NADH oxidized per minute) per litre $^{1}$ under the reaction conditions defined.

Alternatively the NADH may be measured fluorimetrically (Laursen and Hansen, 1958), and this procedure has been adapted to an end-point system for use in the AutoAnalyzer (Levine and Hill, 1965) but it is unsuitable for use as a reference method.

Similar principles are cmployed in the measurement of alanine transaminase (ALT) activity. In the spectrophotometric procedure (Henley and Pollard, 1955), the pyruvate produced in the transaminase reaction (3) is reduced to lactate by the $\mathrm{NAD}^{+}$dependent lactate dehydrogenase (4):

$$
\begin{aligned}
& \text { Alanine }+ \text { 2-oxoglutarate } \rightleftharpoons \text { glutamate }+ \\
& \begin{array}{llllll}
\text { pyruvate } & . & \ldots & \ldots & \ldots & \ldots
\end{array} \\
& \text { Pyruvate }+\mathrm{NADH}+\mathrm{H}^{+} \underset{\text { dehydrogenase }}{\stackrel{\text { lactate }}{\rightleftharpoons}} \\
& \text { lactate }+\mathrm{NAD}^{+} \ldots \quad \ldots \quad \ldots \quad \ldots
\end{aligned}
$$

\section{Substrate Concentrations}

Henry et al (1960) modified the AST technique by adjusting the substrate concentrations to give considerably higher enzyme activities. The L-aspartate concentration $(0.033 \mathrm{moles} /$ litre $)$ employed in Karmen's original spectrophotometric procedure for the determination of AST (Karmen, 1955) was found to be suboptimal, and Henry et al (1960) recommended increasing this to $0.125 \mathrm{moles} / \mathrm{litre}$. DLaspartate cannot be used as the $\mathrm{D}$ - form inhibits this transaminase.

Although Henry et al (1960) increased the final concentration of L-alanine to $0.167 \mathrm{moles} / \mathrm{litre}$ in the measurement of ALT activity, experience has since shown that this concentration is suboptimal (Arvan and Coyle, 1969; Laudahn, Hartmann, Rosenfeld, Weyer, and Muth, 1970). Arvan and Coyle (1969) recommended the use of 0.25 moles/ litre L-alanine, since higher concentrations (such as the $0 \cdot 81$ moles/litre L-alanine, recommended ${ }^{2}$ by Laudahn et al (1970) ) caused little further enhancement of activity and led to difficulty in preparing stock solutions, owing to the limited solubility of this amino acid. Since D-alanine does not act as a

\footnotetext{
${ }^{1}$ The international unit of enzyme activity $(U$ or iu) has not been adapted for use with the SI system (Système Internationale d'Unités). The IUPAC/IUB Commission on Biochemical Nomenclature have instead recommended the 'katal' as the unit of 'catalytic amount', defined as the amount of a catalyst (including an enzyme) that brings about the transformation of one mole of substrate per second under defined conditions. Thus 1 katal per litre (kat/l) $=60 \because 10^{6}$ international units per litre $(U / 1)$ or $1 \mathrm{U} / 1 \bumpeq 16.67 \mathrm{nkat} / 1$.

${ }^{2}$ The Boehringer optimized test combination.
}

substrate for ALT and in our experience does not appear to inhibit the enzyme, DL-alanine may be used in place of L-alanine. The necessary two-fold increase in concentration, however, complicates the use of the DL-form, which is liable to crystallize from stock solutions during storage in a refrigerator.

The reference methods recommended in this report are those of Henry et al (1960), slightly modified in that measurements are made at $25^{\circ} \mathrm{C}$, and a final concentration of 0.25 moles/litre Lalanine is used for the ALT reaction.

\section{Temperature}

Karmen (1955) performed his reaction at 'room temperature' $\left(23^{\circ} \mathrm{C}\right)$ and Henry et al $(1960)$ specified $32^{\circ} \mathrm{C}$, the temperature reached in the cell compartment of the Beckman DU spectrophotometer. The International Union of Biochemistry originally recommended $25^{\circ} \mathrm{C}$, but later $30^{\circ} \mathrm{C}$, for enzyme determination, but few clinical laboratories in Britain carry out enzyme measurements at $30^{\circ} \mathrm{C}$, since in this country it is quite practicable to maintain a temperature of $25^{\circ} \mathrm{C}$ in a thermostatically controlled cuvette compartment of a spectrophotometer for most of the year without the aid of an external cooling unit other than tap water.

The development of semi-automated enzyme rate analyzers, such as the LKB, or spectrophotometers specially adapted for microanalysis, such as the Eskalab, which operate at $35^{\circ} \mathrm{C}$ or $37^{\circ} \mathrm{C}$, has necessitated further review of operating temperatures. There is much to be gained by performing all NADor NADP-dependent enzyme measurements at a single temperature, but the Working Party has not been able to recommend a universally satisfactory temperature. The choice appears to lie between $25^{\circ} \mathrm{C}, 30^{\circ} \mathrm{C}, 35^{\circ} \mathrm{C}$, and $37^{\circ} \mathrm{C}$. We at first considered $37^{\circ} \mathrm{C}$ as the most suitable, since the phosphatases and other enzymes are regularly determined at this temperature and every clinical laboratory is equipped with a $37^{\circ} \mathrm{C}$ water bath. However, doubts were felt about the stability of certain enzymes at $37^{\circ} \mathrm{C}$, in particular liver lactate dehydrogenase (LD-5) and glucose 6-phosphate dehydrogenase (GPD). While the Working Party has been unable to obtain evidence of loss of activity of the former at $37^{\circ} \mathrm{C}$, the latter loses about $15 \%$ of its activity during preincubation for 20 minutes at $37^{\circ} \mathrm{C}$.

The Working Party has some reservations about proposing a temperature other than that recommended by the International Union of Biochemistry and endorsed by the International Federation of Clinical Chemistry, namely $30^{\circ} \mathrm{C}$, but the fact has to be faced that this figure has not proved acceptable in most British clinical laboratories. 
The original IUB recommendation of $25^{\circ} \mathrm{C}$ has been criticized mainly because of the technical difficulty of maintaining it in hot countries and especially in the USA, but during the past decade, several moderately priced refrigerated water baths or portable refrigerator units have been marketed which overcome this problem. We therefore consider that it is practicable to standardize the determination of NAD- and NADP-dependent enzymes at $25^{\circ} \mathrm{C}$. The procedures described are designed for use at $25^{\circ} \mathrm{C}$, but the conditions recommended may not be optimal at higher temperatures. The following conversion factors have been experimentally determined with the suggested method at $37^{\circ} \mathrm{C}$ on six sera with AST and ALT activities ranging from 47 to $184 \mathrm{U} /$ litre and 46 to $139 \mathrm{U} /$ litre respectively. ${ }^{3}$ While these enable results obtained at $37^{\circ} \mathrm{C}$ to be compared with those measured at $25^{\circ} \mathrm{C}$, such factors should be used with caution.

\begin{tabular}{llll}
\hline Cuvette Temperature & Factors to Convert to & $A S T$ & $A L T$ \\
\hline $25^{\circ} \mathrm{C}$ & $37^{\circ} \mathrm{C}$ & 2.18 & 1.96 \\
$37^{\circ} \mathrm{C}$ & $25^{\circ} \mathrm{C}$ & 0.46 & 0.51 \\
\hline
\end{tabular}

Factors for the interconversion of $A S T$ and $A L T$

activities determined at $25^{\circ} \mathrm{C}$ or $37^{\circ} \mathrm{C}$

The Working Party considers that individual laboratories should use whatever temperature is appropriate to their equipment, but should calibrate their procedures with the aid of a suitable reference method. Whatever temperature of estimation may be chosen in a particular laboratory, it is essential to use a spectrophotometer equipped with effective means of controlling the temperature of the sample accurately and precisely.

\section{Recommended Method}

\section{REAGENTS}

Distilled or demineralized water should be used for the preparation of the following reagents:

\section{Phosphate buffer (1.0 moles/litre), $\mathrm{pH} 7 \cdot 4$}

One hundred and thirty-six $\mathrm{g} \mathrm{KH}_{2} \mathrm{PO}_{4}$ and $33 \mathrm{~g}$ $\mathrm{NaOH}$ dissolved in water and the volume adjusted to 1 litre.

2 Phosphate buffer (0.1 moles/litre), $\mathrm{pH} 7 \cdot 4$

One hundred $\mathrm{ml}$ of $1 \mathrm{M}$-phosphate buffer made up to 1 litre and adjusted to $p \mathrm{H} 7 \cdot 4$ at $25^{\circ} \mathrm{C}$.

\footnotetext{
${ }^{3} A$ working party of the Association of Clinical Biochemists is currently investigating the reproducibility of temperature coefficients for AST and ALT determined by the methods described.
}

\section{NADH solution}

$2.5 \mathrm{mg}$ per $\mathrm{ml}$ reagent 2 . Best prepared fresh each day. The development of inhibitors of some de- 으 hydrogenases in certain NADH solutions is not a critical factor when used for transaminase deter- $\stackrel{\vec{S}}{\rightarrow}$ mination as the dehydrogenase used as indicator enzyme is present in considerable excess. Slight variations between batches of good quality NADH $\frac{\bar{\sigma}}{\sigma}$ have negligible effects on the results of transaminase $\stackrel{\mathbb{\Omega}}{\varrho}$ assays.

\section{2-Oxoglutarate $(0.1$ moles/litre)}

$0.73 \mathrm{~g}$ 2-oxoglutaric acid is dissolved in $35 \mathrm{ml}$ water. Five $\mathrm{ml}$ reagent 1 is added and the $\mathrm{pH}$ adjusted to? 7.4 at $25^{\circ} \mathrm{C}$ by the addition of $\mathrm{NaOH}(1 \mathrm{~mole} / \mathrm{litre})$, ? after which the volume is made up to $50 \mathrm{ml}$ with o water. May be stored up to one month at $4^{\circ} \mathrm{C}$.

\section{L-Aspartate (0.375 moles/litre)}

$5.0 \mathrm{~g} \mathrm{~L}$-aspartic acid is dissolved with the aid of 을 heat in a mixture of $50 \mathrm{ml}$ water and $35 \mathrm{ml} \mathrm{NaOH}-$ (1 mole/litre). After cooling to room temperature, $z$ $10 \mathrm{ml}$ reagent 1 is added and the $p \mathrm{H}$ adjusted to $7.4 \$$ at $25^{\circ} \mathrm{C}$ with $\mathrm{NaOH}(1 \mathrm{~mole} / \mathrm{litre})$. The volume is 3 then made up to $100 \mathrm{ml}$. May be stored up to one month at $4^{\circ} \mathrm{C}$.

\section{L-Alanine ( 0.75 moles/litre)}

$6.67 \mathrm{~g} \mathrm{~L}$-alanine is dissolved in $75 \mathrm{ml}$ water and 10 reagent 1 , and the $p \mathrm{H}$ is adjusted to 7.4 at $25^{\circ} \mathrm{C}$ with $\mathrm{NaOH}$ ( $1 \mathrm{~mole} / \mathrm{litre})$. The volume is then made up to $100 \mathrm{ml}$. May be stored for one month at $4^{\circ} \mathrm{C}$.

\section{Malate dehydrogenuse $5 \mathrm{U}$ per $\mathrm{ml}$}

A commercial preparation should be diluted with water to provide a day's supply. Each batch of malate dehydrogenase should be checked for the presence of AST activity by performing a blank reaction, ie, omitting serum, and also for apotransaminase by carrying out a blank reaction in which serum is replaced by $0.2 \mathrm{ml}$ solution containing $0.2 \mu \mathrm{g}$ phosphopyridoxal (Rosalki and Wilkinson, 1959). The presence of the apotransaminase must be excluded since it would be activated by the phos- $\frac{T}{2}$ phopyridoxal of serum to give a spuriously high transaminase activity.

\section{Lactate dehydrogenase $5 \mathrm{U}$ per $\mathrm{ml}$}

The rabbit-muscle enzyme should be diluted with $\omega$ water to provide a day's supply.

\section{PROCEDURE}

The following mixtures are prepared and incubated for $15 \mathrm{~min}$. at $25^{\circ} \mathrm{C} \pm 0 \cdot 2^{\circ} \mathrm{C}$. 


\begin{tabular}{lll}
\hline & $A S T(m l)$ & $A L T(m l)$ \\
\hline Phosphate buffer (0.1 moles/litre) & $1 \cdot 3$ & $1 \cdot 3$ \\
Serum & $0 \cdot 2$ & $0 \cdot 2$ \\
NADH solution & $0 \cdot 2$ & 0.2 \\
L-aspartate & $1 \cdot 0$ & - \\
L-alanine & - & $1 \cdot 0$ \\
Malate dehydrogenase & $0 \cdot 1$ & - \\
Lactate dehydrogenase & - & $0 \cdot 1$ \\
Total volume & $2 \cdot 8$ & 2.8 \\
\hline
\end{tabular}

An ultra-violet spectrophotometer, preferably a recording instrument, is switched on and set for recording changes in absorbance at $340 \mathrm{~nm}$. The cuvette compartment should be thermostatically controlled so that the cuvette temperature is $25^{\circ} \mathrm{C} \pm$ $0 \cdot 2^{\circ} \mathrm{C}$. When the instrument is ready the incubated solutions should be transferred to cuvettes. In each case, the reaction is started by the addition of $0.2 \mathrm{ml}$ 2-oxoglutarate solution followed by careful mixing. Recordings for the purpose of calculation should not be made until the reaction obeys zero-order kinetics, ie, the decrease in absorbance becomes steady. (There is often a lag phase of 2 to $5 \mathrm{~min}$.) The rate of change in absorbance per minute is measured $(\Delta \mathrm{A} / \mathrm{min})$, and the transaminase activity calculated in $\mathrm{U}$ per litre:

Transaminase activity $=\frac{\Delta \mathrm{A} / \mathrm{min}}{6 \cdot 22 \times 10^{3}} \times \frac{1000}{0 \cdot 2} \times 3000$

$$
=\Delta \mathrm{A} / \mathrm{min} \times 2400 \mathrm{U} / \text { litre }
$$

The spectrophotometric unit introduced by Karmen (1955) is the enzyme activity in $3 \mathrm{ml}$ reaction mixture producing a change in absorbence at $340 \mathrm{~nm}$ of 0.001 per minute per $\mathrm{ml}$ of serum. Thus Karmen units/ml can be converted into International units per litre by multiplying by $3 / 6 \cdot 22$ or $0 \cdot 48$.

It is important to check the absorbence scale of the spectrophotometer, since the value of the method depends upon accurate measurement. Methods for checking accuracy with spectrophotometric standards have recently been discussed by Rand (1969).

\section{Normal Ranges for Serum Transaminase Activities}

The normal ranges were obtained at $25^{\circ} \mathrm{C}$ on healthy blood donors and laboratory personnel by the methods described:

Alanine transaminase $\begin{cases}\text { males } & 5-15 \mathrm{U} / \text { litre } \\ \text { females } & 5-12 \\ \text { males } & 5-19 \\ \text { females } & 5-12\end{cases}$

\section{Calibration of Automated and Manual Procedures}

The problems involved in the calibration of automated transaminase procedures are similar to those encountered in the case of alkaline phosphatase discussed in the first report of the Working Party. The most commonly used automated systems include the AutoAnalyzer methods with 2,4dinitrophenylhydrazine (Fingerhut, Ferzola, Marsh, and Levine, 1962) or a diazonium reagent (Schaffert, Kingsley, and Getchell, 1964), but the fluorimetric AutoAnalyzer method (Levine and Hill, 1965) also requires calibration.

For this purpose it is suggested that the transaminase activities of a series of about five sera ${ }^{4}$ be determined by the reference methods described in this report. The activities should span the effective range of the automated technique, ie, from about 10-300 U/litre. The reference sera may be stored frozen in small containers for periods of up to eight months, or at $4^{\circ} \mathrm{C}$ for up to one week without significant loss of activity. Nevertheless we recommend that the activities of such sera be checked at least twice a week.

Non-automated manual versions of these colorimetric or fluorimetric techniques can be calibrated in a similar manner using sera whose transaminase activities have been measured by the reference method.

\section{Comments and Recommendations}

1 Spectrophotometric methods are considered to be the most suitable reference procedures for transaminase determination. The rate of oxidation of $\mathrm{NADH}$, when measured by the change in the absorbance at $340 \mathrm{~nm}$ is a much more dependable standard than any of the alternatives which have been proposed, eg, pyruvate, 'standard' sera, etc. Since the indicator enzymes are in considerable excess the presence of possible dehydrogenase inhibitors in the NADH (Fawcett, Ciotti, and Kaplan, 1961; Dalziel, 1961) has little or no effect on the transaminase reaction which remains the rate-determining step.

2 Transaminase activities determined by a colorimetric technique should not be reported in spectrophotometric units, eg, Karmen units, unless the method has been calibrated by reference to the recommended or other appropriate spectrophotometric procedure.

3 The techniques recommended have been demonstrated to give maximal activities and to be repro-

\footnotetext{
If pools of human sera are used, care should be taken in case some specimens contain hepatitis virus. Horse serum with added liver extracts free from Australia antigen may be used. See First Report of Working Party (Moss et al, 1971). If liver extracts are employed they should be centrifuged to remove mitochondria since mitochondrial glutamate dehydrogenase might catalyse the reductive amination of 2-oxoglutarate by ammonium salts present in the malate dehydrogenase preparation.
} 
ducible, a day-to-day coefficient of variation of $\pm 5 \%$ being obtained on sera with borderline and moderately elevated transaminase activities.

4 The methods of standardization described in this report are applicable to other enzyme procedures dependent upon the oxidation of NADH or NADPH, eg, lactate dehydrogenase, or the reduction of $\mathrm{NAD}^{+}$or $\mathrm{NADP}^{+}$, eg, glucose 6-phosphate dehydrogenase.

\section{References}

Arvan, D. A., and Coyle, M. (1969). Serum and tissue alanine aminotransferase (GPT) based upon optimal substrate concentration. Clin. Chem., 15, 785.

Babson, A. L., Shapiro, P. O., Williams, P. A. R., and Phillips, G. M. (1962). The use of a diazonium salt for the determination of glutamic-oxalacetic transaminase in serum. Clin. chim. Acta, 7, 199-205.

Boyd, J. W. (1961). The intracellular distribution, latency and electrophoretic mobility of L-glutamate-oxaloacetate transaminase from rat liver. Biochem. J., 81, 434-441.

Dalziel, K. (1961). An inhibitor of liver alcohol dehydrogenase in preparations of reduced diphosphopyridine nucleotide. Nature (Lond.), 191, 1098-1099.

Fawcett, C. P., Ciotti, M. M., and Kaplan, N. O. (1961). Inhibition of dehydrogenase reactions by a substance formed from reduced diphosphopyridine nucleotide. Biochim. biophys. Acta, 54, 210-212.

Fingerhut, B., Ferzola, R., Marsh, W. H., and Levine, W. H. (1962). An automated method for a colorimetric determination of serum glutamic oxalacetic transaminase. Ann. N.Y. Acad. Sci., $102,137-143$

Henley, K. S., and Pollard, H. H. (1955). A new method for the determination of glutamic oxalacetic and glutamic pyruvic transaminase in plasma. J. Lab. clin. Med., 46, 785-789.

Henry, R. J., Chiamori, N., Golub, O. J., and Berkman, S. (1960). Revised spectrophotometric methods for the determination of glutamic oxalacetic transaminase, glutamic pyruvic transaminase and lactic acid dehydrogenase. Amer. J. clin. Path., 34, 381-398.

Karmen, A. (1955). A note on the spectrophotometric assay of glutamic-oxalacetic transaminase in human blood serum. J. clin. Invest., 34, 131-133.

Laudahn, G., Hartmann, M., Rosenfeld, B. M., Weyer, H., and Muth, H. W. (1970). Normalwerte der Serum-Transaminasen bei Verwendung substratoptimierter Testansatze zur Aktivitatsmessung. Untersuchungsergebnisse bei 3979 Klinisch gesunden Werktätigen beiderlei Geschlechts. Klin. Wschr., 48, 838-847.

Laursen, T., and Hansen, P. F. (1958). A fluorimetric method for $\overrightarrow{0}$ measuring the activity in serum of the enzyme glutamic : pyruvic transaminase. Scand. J. clin. Lab. Invest., 10, 53-58.

Levine, J. B., and Hill, J. B. (1965). Automated fluorometric determinations of serum glutamic oxalacetic transaminase and serum glutamic pyruvic transaminase. In Automation in $\bar{O}$ Analytical Chemistry, p. 569. Technicon Symposium, New York.

Moss, D. W., Baron, D. N., Walker, P. G., and Wilkinson, J. H. (1971). Standardization of clinical enzyme assays. First report of a Working Party with special reference to alkaline phosphatase estimation. J. clin. Path., 24, 740-743.

Rand, R. N. (1969). Practical spectrophotometric standards. Clin. Chem., 15, 839-863.

Reitman, S., and Frankel, S. (1957). A colorimetric method for the determination of serum glutamic oxalacetic and glutamic pyruvic transaminases. Amer. J. clin. Path., 28, 56.63.

Rosalki, S. B., and Wilkinson, J. H. (1959). A source of error in serum glutamic-oxaloacetic transaminase determination. $J$. clin. Path., 12, 138-139.

Schaffert, R. R., Kingsley, G. R., and Getchell, G. (1964). Automated determination of serum glutamic oxalacetic and glutamic pyruvic transaminase. Clin. Chem., 10, 519-532. 